\title{
Slum Health: Arresting COVID-19 and Improving Well-Being in Urban Informal Settlements
}

\author{
Jason Corburn • David Vlahov • Blessing Mberu • Lee Riley • Waleska Teixeira Caiaffa • \\ Sabina Faiz Rashid • Albert Ko • Sheela Patel • Smurti Jukur • Eliana Martínez-Herrera • \\ Saroj Jayasinghe • Siddharth Agarwal • Blaise Nguendo-Yongsi • Jane Weru • Smith Ouma • \\ Katia Edmundo • Tolu Oni • Hany Ayad
}

(C) The New York Academy of Medicine 2020, corrected publication 2021

\begin{abstract}
The informal settlements of the Global South are the least prepared for the pandemic of COVID-19 since basic needs such as water, toilets, sewers, drainage, waste collection, and secure and adequate housing
\end{abstract}

J. Corburn $(\bowtie)$

School of Public Health \& Department of City \& Regional Planning, University of California, Berkeley, CA, USA

e-mail: jcorburn@berkeley.edu

D. Vlahov

Yale School of Nursing, Orange, CT, USA

e-mail: David.Vlahov@yale.edu

B. Mberu

Urbanization and Wellbeing Unit, African Population and Health Research Centre (APHRC), Nairobi, Kenya

e-mail: bmberu@aphrc.org

\section{Riley}

Infectious Diseases and Vaccinology, School of Public Health, University of California, Berkeley, CA, USA

e-mail: 1riley@berkeley.edu

\section{W. T. Caiaffa}

Epidemiology and Public Health, Federal University of Minas Gerais School of Medicine, Belo Horizonte, Brazil

e-mail: caiaffa.waleska@gmail.com

\section{S. F. Rashid}

Brac School of Public Health, Brac University, Dhaka,

Bangladesh

e-mail: sabina@bracu.ac.bd

A. Ko

Epidemiology of Microbial Diseases, Yale School of Public

Health, New Haven, CT, USA

e-mail: albert.ko@yale.edu are already in short supply or non-existent. Further, space constraints, violence, and overcrowding in slums make physical distancing and self-quarantine impractical, and the rapid spread of an infection highly likely.

\section{S. Patel $\cdot$ S. Jukur}

Society for the Promotion of Area Resource Centre (SPARC), Mumbai, India

$$
\begin{aligned}
& \text { S. Patel } \\
& \text { e-mail: sparc84@gmail.com } \\
& \text { S. Jukur } \\
& \text { e-mail: smrutisj@gmail.com }
\end{aligned}
$$

E. Martínez-Herrera

Research Group of Epidemiology, University de Antioquia,

Medellín, Colombia

e-mail: eliana.martinez@udea.edu.co

S. Jayasinghe

University of Colombo, Colombo, Sri Lanka

e-mail: saroj@clinmed.cmb.ac.lk

S. Agarwal

Urban Health Resource Centre, Delhi, India

e-mail: a.siddharth.in@gmail.com

B. Nguendo-Yongsi

Université de Yaoundé II-Cameroon, Soa, Cameroon

e-mail: sir_nguendoyongsi@hotmail.com

J. Weru

Akiba Mashinani Trust (AMT), Nairobi, Kenya

e-mail: janeweru1@gmail.com 
Residents of informal settlements are also economically vulnerable during any COVID-19 responses. Any responses to COVID-19 that do not recognize these realities will further jeopardize the survival of large segments of the urban population globally. Most top-down strategies to arrest an infectious disease will likely ignore the often-robust social groups and knowledge that already exist in many slums. Here, we offer a set of practice and policy suggestions that aim to (1) dampen the spread of COVID-19 based on the latest available science, (2) improve the likelihood of medical care for the urban poor whether or not they get infected, and (3) provide economic, social, and physical improvements and protections to the urban poor, including migrants, slum communities, and their residents, that can improve their long-term well-being. Immediate measures to protect residents of urban informal settlements, the homeless, those living in precarious settlements, and the entire population from COVID-19 include the following: (1) institute informal settlements/slum emergency planning committees in every urban informal settlement; (2) apply an immediate moratorium on evictions; (3) provide an immediate guarantee of payments to the poor; (4) immediately train and deploy community health workers; (5) immediately meet Sphere Humanitarian standards for water, sanitation, and hygiene; (6) provide immediate food assistance; (7) develop and implement a solid waste collection strategy; and (8) implement immediately a plan for mobility and health care. Lessons have been learned from earlier pandemics such as HIV and epidemics such as Ebola. They can be applied here. At the same time, the opportunity exists for public health, public administration,

\section{S. Ouma}

Cardiff Law and Global Justice, Cardiff, UK

e-mail: oumaso@cardiff.ac.uk

K. Edmundo

Centro de Promoção da Saúde, Rio de Janeiro, Brazil

T. Oni

MRC Epidemiology unit, University of Cambridge, UK \& School of Public Health and Family Medicine, Cambridge, UK

T. Oni

University of Cape Town, Cape Town, South Africa

H. Ayad

Alexandria University, Alexandria, Egypt international aid, NGOs, and community groups to innovate beyond disaster response and move toward longterm plans.

Keywords Slums · Informal settlements · Equity · Coronavirus $\cdot$ Community health $\cdot$ Global health

\section{Introduction}

The COVID-19 pandemic has expanded to the Global South. The epidemiology highlights the challenges for containment, mitigation, and control in low-resourced settings and suggests that the most vulnerable groups, particularly those living in informal habitats and depending on informal livelihoods in the Global South, demand attention. As detailed elsewhere [1], transmission of the virus is by direct contact and droplet spread with cough and sneeze. The most infectious period appears to be when a person is symptomatic, but data point to transmission that can occur before onset of symptoms [2]. A study has shown that the virus is detectable for some time on surfaces, aerosols, and stool [3], but the focus on reducing transmission has been promoting physical distancing between people, vigorous hand washing with clean water and soap, not touching one's face after touching potentially contaminated surfaces and before hand washing, self-isolation for those with symptoms, and self-quarantine for 14 days after an exposure. On the economic front, recommendations such as working from home have become the default function for workers all over the world. Following these guidelines has been a challenge in the Global North. As the pandemic expands to the Global South, the challenges are greater. The purpose here is to provide a focus on a highly vulnerable population - residents of urban and peri-urban informal settlements. There are conditions to recognize and roles to play among the various actors working in this space, namely, country and local governments, bilateral and multi-lateral agencies, foundations, community-based organizations (CBOs), and non-governmental organizations (NGOs).

The close to one billion people that are estimated to live in urban slums or informal settlements are highly susceptible to COVID-19 infection since basic needs such as water, toilets, sewers, drainage, waste collection, and secure and adequate housing are already in short supply or non-existent [4-7]. Further, space constraints, violence, and overcrowding in slums and tenements 
make physical distancing and self-quarantine impractical, and the rapid spread of an infection highly likely [8] [9] [10] [11]. Pre-existing comorbidities likely increase COVID-19 vulnerability. Residents of informal settlements are also economically vulnerable during any COVID-19 responses, since most urban poor living in slums are informal workers, meaning they must show up to earn daily wages, and this daily income is used for subsistence [12]. Any responses to COVID-19 that do not recognize these realities will further jeopardize the survival of large segments of the urban population globally.

An equitable approach to arresting the COVID-19 pandemic must change standard ways of treating the urban poor, create more participatory governance, improve the delivery of essential services including health care, and invest new resources to ensure urban informal settlements benefit in the long term [13]. However, governments have already begun to impose draconian quarantine and physical distancing measures for the urban poor without also ensuring that those residing in urban slums can meet their everyday needs, such as food and clean water [14]. Racism, xenophobia, and stigma against the poor, migrants, and lower classes have also increased during the COVID-19 pandemic [15]. Global COVID-19 responses should coordinate strategies to ensure that large percentages of the urban populations in low-income countries no longer have to live in extreme poverty [16].

Most top-down strategies to arrest an infectious disease will likely ignore the often-robust social groups and knowledge that already exist in many slums. Here, we offer a set of practice and policy suggestions that aim to (1) help stop the spread of COVID-19 based on the latest available science, (2) improve the likelihood of medical care for the urban poor whether or not they get infected, and (3) provide economic, social, and physical improvements and protections to the urban poor, including migrants, slum communities, and their residents, that can improve their long-term well-being [17]. We hope these suggestions can not only respond to the urgent needs of this pandemic and prevent millions of deaths but also offer a more humane and equitable approach to improving the living conditions of the urban poor around the world [18].

A key starting point for these recommendations is a recognition that residents of informal settlements are human beings, not just a percent of the population or cases, and all coronavirus responses must prioritize human dignity and not unfairly burden already vulnerable populations and communities. Second, we begin with an emphasis on information transparency and including communities of slum dwellers directly in decision-making, especially those that may already be vulnerable to infection, such as older people, persons with disabilities, and other regularly excluded subgroups. Third, preventing the spread of coronavirus should not come at the expense of slum dwellers' existing needs, from housing to water and sanitation to primary health care to employment and political recognition. Fourth, all slums we know about and work with have assets, even among the widespread deprivation, that can be utilized to share information, prevent exposure, and support over-all well-being. Fifth, investing in the health and well-being of the urban poor and residents of slums first will ultimately prevent disease reservoirs that would eventually spillover into the general population. So, we call on governments to prioritize the humanity, dignity, and assets of residents of urban slums and their communities; to engage with residents, migrants, and the urban poor more generally to find ways to improve their well-being; and to co-create solutions between residents of urban informal settlements and medical, public health, and other experts.

We also recognize that urban slums are the sources of substantial economic activity in cities and countries, such as through micro-enterprises and informal labor $[19,20]$, and any response to COVID-19 should balance economic well-being and epidemic mitigation. Those living in urban informal settlements often rely on robust social connections to survive, such as to identify day labor, to get food using credit from a street vendor, or to find trustworthy child care providers, just to name a few [21]. Schools, service providers, and faith-based organizations in urban informal settlements, as well as traditional leaders, CBOs, and NGOs are also crucial institutions that must be engaged and supported during a coordinated COVID-19 response. Thus, we offer the following measures for all local and national governments to integrate into their COVID-19 responses.

Immediate measures to protect residents of urban informal settlements, the homeless, those living in precarious settlements, and the entire population from COVID-19:

(1) Create informal settlements/slum emergency planning committees in every urban informal settlement. These committees must be networked across 
a settlement (since large slums have hundreds of thousands of residents and smaller villages or districts within them), across entire metropolitan regions and across all cities in a country. Governments should avoid top-down directives forced upon residents of informal settlements. A key lesson from the Ebola outbreak in the slums of Monrovia, Liberia, was that mistrust between the poor and medical and public health professionals contributed to misinformation and treatment delays; less appreciated was that slum residents had innovative ideas about how to improve hygiene and well-being [22]. Those already living on the streets and in slums likely have a legitimate mistrust and fear of government and outsiders claiming to help, since these institutions can be perceived as oppressive and interested in stymying political opposition [23, 24]. There are existing models of intra-slum settlement, inter-city, and global networks of mobilized slum dwellers that can coordinate COVID-19 response teams, such as those developed by Shack Dwellers International (SDI) [25]. Of course, there can be many NGOs working in urban slums, the homeless urban poor may not be easily reached or organized, and not all NGOs may prioritize the interests of or directly support the local people. There are likely some pre-existing organized community groups, as well as NGOs skilled in disaster prevention and response [26], public health, preventing genderbased and ethnic violence, and with mobilizing hard-to-reach populations such as youth gang members [27], and all these should be identified early in this process [28-30]. The experts from SDI and similar organizers of the urban poor can help ensure the diverse cultures, religions, and ethnicities that often exist side by side in urban slums, as well as any conflicts that may be present, are acknowledged as place-specific plans for disease prevention, potential isolation, and physical distancing. Community-led committees must also be empowered to lead on the public health and disease messaging, including avoiding xenophobic and racist falsities [31], and help decide the appropriate use of technologies in communication to those who may be illiterate or have minimal health or science education $[32,33]$.

(2) Immediate moratorium on evictions [34]. Displacement, eviction, and homelessness are adverse determinants of health and can contribute to susceptibility of infection [35-37]. Forced evictions, sometimes in the name of hygiene and dispersing dense slum populations to avoid communicable disease spread, have regularly contributed to greater spread of disease among both the displaced populations and the general population $[38,39]$. Displacing residents of urban slums can not only contribute to transmission and acquisition of infections but can have long-term physical and mental health impacts, especially for women and children [40, 41]. Many residents of urban slums are regularly traveling, as they seek work, food, services, and connect back to their families in rural villages and towns $[42,43]$. Physical distancing measures, if implemented, must consider the dynamic nature of slum populations, the crowded living conditions, and the dependencies of care and resources for those living outside the city.

Governments should also immediately identify land within $3 \mathrm{~km}$ of existing settlements (in close proximity to ensure residents can retain social ties) that can be used for any shelter relocation or de-densification measures, if necessary. Possible land should include sports facilities, closed universities, military land, and even private sector space. This additional land should also be identified for temporary emergency health care triage (including temporary isolation centers to house families and their contacts), and, in the long term, this land should be considered for new, low-income housing.

(3) Immediate guarantee of payments to the poor. Governments must provide new, additional financial supports directly to the urban poor to offset any loss of employment and to support their health [44]. These payments must compensate for the impacts of any proposed COVID-19 prevention measures, such as social distancing, that will eliminate day labor, employment as domestic servants in higher-income neighborhoods, and the street economies of urban slums. The payment amounts should be negotiated at the local scale, but we suggest a minimum of 3-month living wage salary to the poor, which can cover food, rent, utilities, and other basic needs [45]. Countries can find the resources for these payments when the IMF, World Bank, and bilateral lending institutions immediately end debt interest (and even principal) payments 
for all low-income countries and those with sizeable slum populations, as was recently called for at the G-20 summit by Ethiopian Prime Minister Abiy Ahmed and endorsed by the UN Economic Commission for Africa [46, 47]. Private charities and philanthropy, as well as individual donors, should pool resources into a COVID-19 Emergency Financing Programme for these same countries [45]. The slum dweller payments should be given to all the urban poor, whether or not they can "prove" they are homeless or live in an informal settlement [45]. The payments should, where possible, use established electronic cash transfer means and programs, like Jan Dhan, Aadhaar card, and MNREGA (Mahatma Gandhi National Rural Employment Guarantee Act) in India, m-Pesa in Kenya, Prospera in Mexico, and Colombia's Familias en Acción and Bolsa Familia in Brazil [48]. The goal should be universal access to payments for the urban poor, even if they are not part of a formal program or have an electronic means for disbursement [49].

(4) Immediate community health worker deployment. Many urban informal settlement residents rely on informal health providers as their first entry into the health care system, either due to cost, trust, or access issues [50]. This may be especially true for such common ailments as fevers and coughs, two early indicators of potential infection with novel coronavirus. Informal providers and community health workers may have the trust with local residents to also be able to identify those slum dwellers at higher risk for COVID-19, such as those with HIV, TB, and COPD [51]. We suggest incorporating, not ignoring, the informal providers into all pandemic response plans in the urban slums [52]. Such providers could be key to early detection of cases, and they along with community health workers (CHWs) from each urban slum should be trained to both protect themselves and others, such as by helping detect symptoms and reporting to relevant authorities [53, 54]. CHWs could ensure that all adults age 55 or older and/or with chronic medical conditions received verbal daily screening for symptoms of fever, cough, and respiratory distress, while ensuring continuity of care for their pre-existing conditions. Testing, screening, and contact tracing for COVID-19 infections should be prioritized and done by employing an "army" of slum residents newly trained as CHWs. Youth should be trained alongside CHWs, and together they will be able to advise on which social media platforms (i.e., WhatsApp, etc.) are useful for communication and even contact tracing. Existing apps, such as Ushahidi (https://www.ushahidi. $\mathrm{com} /$ ), should be freely available to act as a platform for real-time options for communicating when a person test positive and mapping where they live and to inform potential contacts. CHWs can also offer social supports to patients who test positive for COVID-19 and their families, more easily communicate with patients' social networks, and ensure the spaces in which they have been living get disinfected. Employing local people and youth as CHWs can also address discrimination and stigmatization that can come with a new disease $[55,56]$.

(5) Immediately met Sphere Humanitarian standards for water, sanitation, and hygiene [57] for all urban informal settlements. Lack of water, sanitation, and clean energy compromise all efforts for hygiene. Community-based slum mapping exercises have regularly shown that few urban slums, particularly in sub-Saharan Africa, meet the minimal standards for water access, toilets per person, sewers, and drainage per household [58, 59]. We prefer reaching standards for non-emergency situations, but know that in the short term, very few slums will be able to meet the WHO recommendations of 501 per person per day of potable water. Sharing of water access points forces residents to spend hours seeking and queuing for water, both of which adversely impact health and economic status [ 60,61]. Lack of these basic services can contribute to increased violence and further spread of disease [62]. We recognize there is no one-size-fits-all for delivering these essential services [63], but governments should explore immediately delivering water trucks, sanitizing stations, and portable toilets. Communities should be consulted, along with local officials, and municipal and national policies should be prepared to develop plans that provide clean water and safe, hygienic, and dignified toilets on a large scale, such as that of India's Swachh Bharat Abhiyan (SBA) or Clean India Mission [64].

(6) Immediate food assistance. Malnutrition and food insecurity is endemic in many urban slums throughout the world [65-68]. Urban slum 
dwellers rely on day wages to purchase food, and street food vending is often a significant source of calories and nutrition $[69,70]$. Schools often provide essential nutrition and meals for children living in slums, and closing those institutions may deny children access to their only consistent meals [71]. Providing produce and proteins for home cooking may also not be adequate, especially if residents of informal settlements are forced to cook inside their structures. Indoor air pollution from cooking [72, 73] can contribute to respiratory infections, a leading cause of morbidity and mortality in urban slums [74]. WHO estimates 7 million people die every year from ambient (outdoor) and household air pollution, with nearly $90 \%$ of deaths occurring in lowand middle-income countries [75]. During any shelter-in-place strategies during the pandemic, safe alternatives to air-polluting indoor cooking must be made available [76]. Governments should support existing CBOs, faith-based groups, and others that may already be providing food support to the poor and ensure they can deliver cooked meals to all those in the informal settlements and living on the streets. Efforts should be made to ensure adequate nutritional content, including protein, of all delivered food.

(7) Solid waste collection strategy. Governments must develop a coordinated solid waste collection strategy for all urban slums. Urban slums largely lack municipal waste collection [77] so residents, youth groups, and/or organized cartels often fill the void [78]. [79] When households are forced to remain in place, additional solid waste will be generated. When refuse is removed, it is often landfilled near other informal settlements, shifting the waste and related disease burdens to another group of urban informal settlements [80]. Solid waste recycling can also be an income-generating activity for some slum dwellers [ 81]. However, intermittent waste collection in urban slums contributes to the regular burning of waste and related unhealthy particulate air pollution and dump sites that act as breeding grounds for other disease vectors (i.e., mosquitos, rats, etc.) that are known to make urban slum dwellers susceptible to dengue, leptospirosis, and other communicable diseases [82, 83]. A key lesson from the Ebola outbreak [84] in 2014 was that quarantines, which were used as a response measure in Guinea, Liberia, and Sierra Leone, resulted in large waste disposal burdens that put an even greater strain on the health of residents of informal settlements.

(8) Immediate plan for mobility and health care. An emergency risk plan that ensures access into and out of the urban slum settlement for emergency vehicles (ambulance, firefighting, etc.) for elderly and disabled persons must be immediately developed [85]. Narrow lanes, steep slopes, river crossings, and other natural and human-made barriers can deny emergency vehicle access to urban slums. Plans made with community residents should identify evacuation routes that are kept clear to ensure those within the settlement that may get sick can get to health care and that emergency services can get into and out of the settlement in timely way. Traveling between urban and rural settings is common for urban informal settlement residents, and any COVID-19 control strategies must understand these linkages to prevent urban-rural transmission.

Deploying mobile clinics should occur immediately to support testing, diagnosis, and early treatment in slums. Most urban slums lack formal health clinics that can provide needed care to a large number of people, and when clinics do exist, cost, distance, and mistreatment by medics are barriers the poor face when seeking care. As noted above, informal and unregulated health care providers proliferate in slums. Mobile clinics can more easily be outfitted with oxygen tanks, nasal cannulae, and oxygen facemasks, as well as other diagnostic tools necessary for the treatment of COVID-19. The mobile units should also be prepared to treat the most common ailments in urban slums, which tend to be diarrhea, upper respiratory infections, and injuries. Large mobile teams of health professionals, doctors, and nurses, with testing kits and, ideally, ventilators and other equipment, could visit multiple slums in the same day. These units could then be quickly deployed wherever the number of reports seems to be growing the fastest. The units will need clinicians skilled in intubation and ventilator support and other advanced life support services. Governments will also need to engage companies that supply advanced life support equipment to make sure such resources are deployed to hospitals that serve the urban poor, and hospitals, be they government, private, or charity, must open up their intensive care units (ICU) to patients from informal settlements. 


\section{Conclusions}

The informal settlements of the Global South are the least prepared for the pandemic of COVID-19. The toll it will take on lives and livelihoods will have immediate and long-lasting effects. The response will need to involve multiple actors that include national and local governments, bilateral and multi-lateral international agencies, CBOs, NGOs, and foundations. There will be a need to provide necessary training, outreach, and services to the residents of settlements where longstanding trust has been developed. All proposed interventions must uphold human rights laws, since the urban poor frequently experience violations of their rights [86]. These resources are needed to address the immediate critical needs of communities and to promote social and economic resilience that extends beyond the immediate crises.

Immediate multidisciplinary research is needed to document how the most vulnerable are managing and coping, to ensure interventions are reducing transmission and disease burdens, and to improve the social, economic, and physical conditions of the urban poor. Participatory research that captures social, cultural, economic, ethnic, gender, and health impacts of all COVID-19 responses is urgently needed [87]. This evidence, if generated using multidisciplinary methods, can also inform learning-by-doing, ensure interventions are adjusted as new data emerges about benefits and burdens, and hold governments, donors, NGOs, and onthe-ground practitioners accountable to the needs of the urban poor.

Lessons have been learned from earlier pandemics such as HIV and epidemics such as Ebola. They can be applied here. At the same time, the opportunity exists for public health, public administration, international aid, NGOs, and community groups to innovate beyond disaster response and move toward long-term plans and actions that improve the well-being of those who now live in informal settlements.

Acknowledgements We acknowledge the input of all coauthors and valuable insights from those living in urban informal settlements around the world.

See Guidelines: Creative Commons and OGL Licence Text for Open Access Content

\section{References}

1. McIntosh K, Coronavirus Disease 2019 (COVID-19) updated 03/31/20. Site: https://www.uptodate. com/contents/coronavirus-disease-2019-covid-19. Accessed 28 Mar 2020.

2. Transmission of 2019-nCoV infection from an asymptomatic contact in Germany. N Engl J Med. 2020;382:970-1. https://doi.org/10.1056/NEJMc2001468.

3. van Doremalen N, et al. Aerosol and surface stability of SARS-CoV-2 as compared with SARS-CoV-1. N Engl J Med. 2020; https://doi.org/10.1056/NEJMc2004973.

4. Lilford RJ, et al. The health of people who live in slums 2: improving the health and welfare of people who live in slums. Lancet. 2016; https://doi.org/10.1016/S0140-6736 (16)31848-7.

5. Riley LW, Ko AI, Unger A, et al. Slum health: Diseases of neglected populations. BMC Int Health Hum Rights. 2007;7(2) https://doi.org/10.1186/1472-698X-7-2.

6. Emina J, Beguy D, Zulu EM, et al. Monitoring of health and demographic outcomes in poor urban settlements: evidence from the Nairobi Urban Health and Demographic Surveillance System. J Urban Health. 2011;88(Suppl 2): S200-18.

7. Lopez, O. \& Moloney, A. Coronavirus chases the slum dwellers of Latin America. Reuters. 2020. https://nationalpost.com/pmn/health-pmn/coronaviruschases-the-slum-dwellers-of-latin-america. Accessed 30 Mar 2020.

8. Snyder RE, et al. Zika: A scourge in urban slums. PLoS Negl Trop Dis. 2017;11(3):e0005287. Published 2017 Mar 23. https://doi.org/10.1371/journal.pntd.0005287.

9. Snyder RE, Marlow MA, Riley LW. Ebola in urban slums: the elephant in the room. Lancet Glob Health. 2014;2(12): e685. https://doi.org/10.1016/S2214-109X(14)70339-0.

10. Key considerations: COVID-19 in informal urban settlements. ht t p s : / / o pendocs.ids.ac. uk/opendocs/bitstream/handle/20.500.12413/15185 /SSHAP_COVID-19_Key_Considerations_Informal Settlements_final.pdf? ${ }_{\text {sequence}}=3 \&$ is Allowed $=\bar{y}$. Accessed 28 Mar $202 \overline{0}$.

11. Agarwal, S.. "The invisible poor." (2011): 20-26. https://papers.ssrn.com/sol3/papers.cfm?abstract $\mathrm{id}=2784879$. Accessed 28 Mar 2020.

12. Mberu BU, Ciera JM, et al. Patterns and determinants of poverty transitions among poor urban households in Nairobi, Kenya. Afr Dev Rev. 2014;26:172-85.

13. Corburn J, Sverdlik A. Slum upgrading and health equity. Int J Environ Res Public Health. 2017;14(4) https://doi. org/10.3390/ijerph14040342.

14. Kimani-Murage EW, Schofield L, Wekesah F, Mohamed S, Mberu B, Ettarh R, et al. Vulnerability to food insecurity in urban slums: experiences from Nairobi, Kenya. J Urban Health. 2014;91:1098-113. https://doi.org/10.1007 /s11524-014-9894-3.

15. Wikipedia. List of incidents of xenophobia and racism related to the 2019-20 Coronavirus pandemic https://en. wikipedia.org/wiki/List_of_incidents_of_xenophobia_and racism_related_to_the $2019 \% \mathrm{E} 2 \% 80 \% \overline{9} 320$ coronavirus pandemic. Accessed 29 Mar 2020. 
16. World Bank. Poverty and shared prosperity 2018: piecing together the poverty puzzle. Washington, DC: World Bank; 2018. License: Creative Commons Attribution CC BY 3.0 IGO. https://www.worldbank.org/en/publication/povertyand-shared-prosperity. Accessed 29 Mar 2020.

17. Corburn J, Riley L, editors. Slum health: From the cell to the street. 1st ed., University of California Press; 2016.

18. https://www.dailymaverick.co.za/article/2020-03-27abahlali-basemjondolo-you-cant-stop-the-virus-whileliving-in-the-mud/?fbclid=IwAR0hBEbVlPkU3uC4 iNyLNfNt4fhrr6yQ7gvSWoO2K-N56nLZesZPDkrh3wg. Accessed 29 Mar 2020.

19. Ellis P, Roberts M. Leveraging urbanization in South Asia: managing spatial transformation for prosperity and livability. Washington, DC: World Bank; 2016.

20. Fox S. Political economy of slums: theory and evidence from sub-Saharan Africa. World Dev. 2014;54:191-203. https://doi.org/10.1016/j.worlddev.2013.08.005.

21. https://www.ilo.org/global/statistics-and-databases/lang\%2 D\%2Den/index.htm. Accessed 29 Mar 2020.

22. Mukpo, A. 2017. Liberia after Ebola: 'The human suffering changed me.' https://www.aljazeera. com/indepth/features/2017/06/liberia-ebola-humansuffering-changed-170618094629264.html. Accessed 30 Mar 2020.

23. Rashid SF. Strategies to reduce exclusion among populations living in urban slum settlements in Bangladesh. $J$ Health Popul Nutr. 2009;27:574-86.

24. Sholihah PI, Shaojun C. Impoverishment of induced displacement and resettlement (DIDR) slum eviction development in Jakarta Indonesia. Int Urban Sustain Dev. 2018;10(3):263-78. https://doi.org/10.1080 /19463138.2018.1534737.

25. Patel S, Burra S, D'Cruz C. Shack/slum dwellers international (SDI) - foundations to treetops. Environ Urban. 2001;13(2):45-59.

26. Macarthy JM, Frediani AA, Kamara SF, Morgado M. Exploring the role of empowerment in urban humanitarian responses in Freetown. IIED Working Paper: IIED; 2017. https://pubs.iied.org/pdfs/10845IIED.pdf

27. Schipani, A. \& Harris, B. (2020). Drug gangs in Brazil's favelas enforce coronavirus lockdown. https://www.ft. com/content/aaef1591-2fc5-4e6f-ab84-0e83b5a146ca. Accessed 30 Mar 2020.

28. Aßheuer T, Thiele-Eich I, Braun B. Coping with the impacts of severe flood events in Dhaka's slums - the role of social capital. Erdkunde. 2013:21-35.

29. Patel R, Walker G, Bhatt M, Pathak V. The demand for disaster microinsurance for small businesses in urban slums: the results of surveys in three Indian cities. PLOS Curr Disasters. 2017 . Edition 1. doi: https://doi.org/10.1371 /currents.dis.83315629ac7cae7e2c4f78c590a3ce1c.

30. Bittencourt BK, et al. Evaluating preparedness and resilience initiatives for distressed populations vulnerable to disasters in Rio de Janeiro, Brazil. Charlottesville, VA: 2013 IEEE systems and information engineering design symposium; 2013. p. 58-63.

31. Teaching Tolerance. How to respond to coronavirus racism. 2020. https://www.tolerance.org/magazine/how-to-respondto-coronavirus-racism. Accessed 30 Mar 2020.
32. Mudgapalli V, et al. Perception of receiving sms based health messages among hypertensive individuals in urban slums. Technol Health Care. 2016;24(1):57-65.

33. van der Heijden J, Gray N, Stringer B, Rahman A, Akhter S, Kalon S, et al. 'Working to stay healthy', health-seeking behaviour in Bangladesh's urban slums: a qualitative study. BMC Public Health. 2019;19:600. https://doi.org/10.1186 /s12889-019-6750-0.

34. Ebrahim S, Hodgson TF. Abahlali baseMjondolo: You can't stop the virus while living in the mud. Maverick Citizen, 27 March 2020. https://www.dailymaverick.co.za/article/202003-27-abahlali-basemjondolo-you-cant-stop-the-viruswhile-living-in-the-mud/

35. Deola C, Patel RB. Health outcomes of crisis driven urban displacement: a conceptual framework. Disaster Health. 2014;2(2):92-6. https://doi.org/10.4161 /21665044.2014.990306.

36. Kouadio IK, Aljunid S, Kamigaki T, Hammad K, Oshitani H. Infectious diseases following natural disasters: prevention and control measures. Expert Rev Anti-Infect Ther. 2012;10(1):95-104. https://doi.org/10.1586/eri.11.155.

37. Puertas G, Ríos C, Valle H. The prevalence of common mental disorders in urban slums with displaced persons in Colombia. Rev Panam Salud Pública. 2006;20(5):324-30. https://doi.org/10.1590/S1020-49892006001000005.

38. Osorio L, Todd J, Bradley DJ. Travel histories as risk factors in the analysis of urban malaria in Colombia. Am J Ttrop Med Hyg. 2004;71(4):380.

39. NAS. Urbanization and slums: infectious diseases in the built environment: Proceedings of a Workshop. Forum on Microbial Threats. Washington (DC): National Academies Press (US); 2018. 3, Understanding Infectious Disease Transmission in Urban Built Environments. Available from: https://www.ncbi.nlm.nih.gov/books/NBK507339/

40. Kim G, Torbay R, Lawry L. Basic health, women's health, and mental health among internally displaced persons in Nyala Province, South Darfur, Sudan. Am J Public Health. 2007;97(2):353-61.

41. Choueiry N, Khawaja M. Displacement and health status in low income women: findings from a population-based study in greater Beirut. J Migr Refug Issues. 2007;3(1):1-13.

42. Glennie, J. Want to know what to do about slum dwellers? Try listening to them. UK Guardian, 2011. https://www. theguardian.com/global-development/poverty-matters/2011 /aug/23/what-to-do-about-slum-dwellers. Accessed 30 Mar 2020.

43. Mberu, B. U., A. C. Ezeh, et al. (2012). "Family ties and urban-rural linkages among older migrants in Nairobi informal settlements." Population, Space and Place. Wiley Online Library. https://doi.org/10.1002/psp.1711.

44. Gentilini, U. Entering the city: emerging evidence and practices with safety nets in urban areas. World Bank, Report \#98253. 2015/07/01. http://documents.worldbank. org/curated/en/656081467980515244/Entering-the-cityemerging-evidence-and-practices-with-safety-nets-in-urbanareas. Accessed 30 Mar 2020.

45. Dufalo, E and Banerjee, A. A prescription for action: nine steps after the next 21 days. Indian Express https://indianexpress.com/article/opinion/columns/indialockdown-coronavirus-infection-abhijit-banerjee-estherduflo-6336624/. Accessed 30 Mar 2020. 
46. Getachew, A. COVID-19: Ethiopia premier seeks debt relief for Africa. 2020. https://www.aa.com.tr/en/africa/covid-19ethiopia-premier-seeks-debt-relief-for-africa/1777564. Accessed 30 Mar 2020.

47. UN ECA. Three things the G20 must do to support Africa in COVID-19 pandemic. 2020. https://www.uneca. org/stories/three-things-g20-must-do-support-africa-covid19-pandemic. Accessed 30 Mar 2020.

48. Vaidyanathan Iyer, P. Rs 1.7 lakh crore Covid-19 package: many who have been hit still left out, relief too little. Indian Express. ht t p s : / / indian express. com/article/explained/coronavirus-relief-package-nirmalasitharaman-left-out-6333639/. Accessed 30 Mar 2020

49. We note that there is also a moral imperative that the wealthy in cities who hire the maids and care-takers etc., from the migrant and urban poor population continue to pay the wages of their employees.

50. Adams AM, et al. Who serves the urban poor? A geospatial and descriptive analysis of health services in slum settlements in Dhaka, Bangladesh. Health Policy Plan. 2015;30(1):i32-45. https://doi.org/10.1093/heapol/czu094.

51. van de Vijver S, Oti S, Oduor C, Ezeh A, Lange J, Agyemang C, et al. Challenges of health programmes in slums. Lancet. 2015;386(10008):2114-6.

52. Amiresmaili M, Yazdi-Feyzabadi V, Heidarijamebozorgi M. Health services utilization among slum dwellers: An experience from Iran. J Educ Health Promot. 2019;8:210. Published 2019 Oct 24. https://doi.org/10.4103/jehp. jehp_358_19

53. Alam K, Oliveras E. Retention of female volunteer community health workers in Dhaka urban slums: a prospective cohort study. Hum Resour Health. 2014;12:-29. Published 2014 May 20. https://doi.org/10.1186/1478-4491-12-29.

54. Mannan MA. Burden of disease on the urban poor: a study of morbidity and utilisation of healthcare among slum dwellers in Dhaka City: Bangladesh Institute of Development Studies; 2018. https://think-asia. org/handle/11540/9487

55. Kerrigan D, Vazzano A, Bertoni N, Malta M, Bastos FI. Stigma, discrimination and HIV outcomes among people living with HIV in Rio de Janeiro, Brazil: the intersection of multiple social inequalities. Global Public Health. 2017;12(2):185-99. https://doi.org/10.1080 /17441692.2015.1064459.

56. Justice \& Empowerment Initiatives (JEI). Corona diaries of the urban poor: Grassroots perspective at a time of pandemic. https://www.justempower.org/coronadiaries. Accessed 30 Mar 2020.

57. Sphere Humanitarian. Humanitarian charter and minimum standards in humanitarian response. https://handbook. spherestandards.org/en/sphere/\#ch001

58. Corburn J, Hildebrand C. Slum sanitation and the social determinants of Women's health in Nairobi. Kenya. J Environ Public Health. 2015;2015:209505. https://doi. org/10.1155/2015/209505.

59. Subbaraman R, O'Brien J, Shitole T, Shitole S, Sawant K, Bloom DE, et al. Off the map: the health and social implications of being a non-notified slum in India. Environ Urban. 2012 Oct;24(2):643-663. PMCID: PMC3565225. https://doi.org/10.1177/0956247812456356
60. Hopewell MR, Graham JP. Trends in access to water supply and sanitation in 31 major sub-Saharan African cities: an analysis of DHS data from 2000 to 2012. BMC Public Health. 2014;14:208. https://doi.org/10.1186/1471-245814-208.

61. Simiyu S, Swilling M, Cairncross S, Rheingans R. Determinants of quality of shared sanitation facilities in informal settlements: case study of Kisumu, Kenya. BMC Public Health. 2017;17:68. https://doi.org/10.1186/s12889016-4009-6.

62. Sommer M, Ferron S, Cavill S, House S. Violence, gender and WaSH: spurring action on a complex, underdocumented and sensitive topic. Environ Urban. 2015;27: 105-16.

63. Buyana Kareem. Understanding the different characteristics of African cities will be crucial in responding effectively to COVID-19 on the continent. ISC. 2020. https://council. science/current/blog/understanding-the-differentcharacteristics-of-african-cities-will-be-crucial-inresponding-effectively-to-covid-19-on-the-continent/

64. Dandabathula G, Bhardwaj P, Burra M, Rao PVVP, Rao SS. Impact assessment of India's Swachh Bharat Mission - clean India campaign on acute diarrheal disease outbreaks: yes, there is a positive change. $J$ Family Med Prim Care. 2019;8(3):1202-8. https://doi.org/10.4103/jfmpc. jfmpc_144_19.

65. Joshi A, Arora A, Amadi-Mgbenka C, Mittal N, Sharma S, Malhotra B, et al. Burden of household food insecurity in urban slum settings. PLoS ONE. 2019;14(4):e0214461. https://doi.org/10.1371/journal.pone.0214461.

66. Kimani-Murage EW, Muthuri SK, Oti SO, Mutua MK, van de Vijver S, Kyobutungi C. Evidence of a double burden of malnutrition in urban poor settings in Nairobi., Kenya. PLoS One. 2015;10:e129943. https://doi.org/10.1371/journal. pone.0129943.

67. Agarwal S, Sethi V, Gupta P, Jha M, Agnihotri A, Nord M. Experiential household food insecurity in an urban underserved slum of North India. Food Sec. 2009;1(3):239-50.

68. Hadley C, Stevenson EG, Tadesse Y, Belachew T. Rapidly rising food prices and the experience of food insecurity in urban Ethiopia: impacts on health and well-being. Soc Sci Med. 2012;75(12):2412-9.

69. Steyn N, Mchiza Z, et al. Nutritional contribution of street foods to the diet of people in developing countries: a systematic review. Public Health Nutr. 2013;17:1363-74. https://doi.org/10.1017/S1368980013001158.

70. Galal O, Corroon M, Tirado C. Urban environment and health: food security. Asia Pac J Public Health. 2010;22(3 Supp1):254S-61S. https://doi.org/10.1177 /1010539510372993.

71. Srivastava A, Mahmood SE, Srivastava PM, Shrotriya VP, Kumar B. Nutritional status of school-age children - a scenario of urban slums in India. Arch Public Health. 2012;70: 8. https://doi.org/10.1186/0778-7367-70-8.

72. Kulshreshtha $P$, Khare M, Seetharaman P. Indoor air quality assessment in and around urban slums of Delhi city, India. Indoor Air. 2008 Dec;18(6):488-98. https://doi.org/10.1111 /j.1600-0668.2008.00550.x.

73. Dianati K, et al. Household air pollution in Nairobi's slums: a long-term policy evaluation using participatory system 
dynamics. Sci Total Environ. 2019;660:1108-34. https://doi. org/10.1016/j.scitotxenv.2018.12.430.

74. Checkley W, Pollard SL, Siddharthan T, Babu GR, Thakur $\mathrm{M}$, Miele $\mathrm{CH}$, et al. Managing threats to respiratory health in urban slums. Lancet. 2016;4(11):852-4. https://doi. org/10.1016/S2213-2600.

75. WHO. 2020. Air Pollution. https://www.who.int/healthtopics/air-pollution\#tab=tab_1

76. Chandran, In slums and windowless apartments, Asia's poor bear brunt of coronavirus. Thomson Reuters Foundation. 2020. https://news.trust.org/item/20200317074850-xs1fr/. Accessed 28 Mar 2020.

77. Mukama, T. et al. Practices, concerns, and willingness to participate in solid waste management in two urban slums in Central Uganda. J Env and Public Health (n.d.) https://doi. org/10.1155/2016/6830163

78. UN. Turning waste into a business in the slums of Yaoundé, Cameroon. 2019 https://news.un.org/en/story/2019/07 $/ 1043541$

79. Schueler, Adriana Soares de, Kzure, Humberto, Racca, Gustavo Badolati. How are municipal waste in the slums of Rio de Janeiro?. urbe, Rev. Bras. Gest. Urbana [online]. 2018, vol.10, n.1, pp. 213-230. ISSN 2175-3369. https://doi. org/10.1590/2175-3369.010.001.ao15

80. Kimani N.G. Environmental pollution and impact to public health: Implication of the Dandora Municipal dumping site in Nairobi, Kenya. Nairobi:UNEP; 2007. https://www.habitants. orgx/content/download/63622/744639/version/1 /file/Report+UNEP+Dandora+Environmental +Pollution+and+Impact+to+Public+Health+(2007).pdf. Accessed 2 April 2020.

81. Buyana K, Byarugaba D, Sseviiri H, Nsangi G, Kasaija P. Experimentation in an African neighborhood: reflections for transitions to sustainable energy in cities. Urban Forum. 2019;30:191-204. https://doi.org/10.1007/s12132-0189358-z.

82. Krystosik A, Njoroge G. Solid wastes provide breeding sites, burrows, and food for biological disease vectors, and urban zoonotic reservoirs: a call to action for solutions-based research. Front Public Health. 2020; https://doi.org/10.3389 /fpubh.2019.00405.

83. Ziraba AK, Haregu TN, Mberu B. A review and framework for understanding the potential impact of poor solid waste management on health in developing countries. Arch Public Health. 2016;74:55. https://doi.org/10.1186/s13690-0160166-4.

84. Campbell L. Learning from the Ebola response in cities: population movement: ALNAP Working Paper. ALNAP/ O D I ; 2017 . h t t p s : / / w w w . a $1 \mathrm{n} \mathrm{a} \mathrm{p} \mathrm{.}$ org/system/files/content/resource/files/main/alnap-urban2017-ebola-population-movement.pdf

85. Mould-Millman NK, Rominski SD, Bogus J, et al. Barriers to accessing emergency medical services in Accra, Ghana: development of a survey instrument and initial application in Ghana. Glob Health Sci Pract. 2015;3(4):577-590. Dec 17. https://doi.org/10.9745/GHSP-D-15-00170. Published 20015 . ht t p s : / / w w w . u r b a n a r k. org/sites/default/files/resources/UrbanArk_briefing_19_2 nd.pdf

86. Chandran, R. Forced evictions illegal, slum dwellers have right to City: Delhi court. Reuters. 20 March 2019. https://www.reuters.com/article/us-india-landrightscourt/forced-evictions-illegal-slum-dwellers-have-right-tocity-delhi-court-idUSKCN1R10V8. Accesssed 18 Mar 2020.

87. Kendi, I. Why don't we know who the Coronavirus victims are? The Atlantic. 2020. https://www.theatlantic. com/ideas/archive/2020/04/stop-looking-away-race-covid19-victims/609250/

Publisher's Note Springer Nature remains neutral with regard to jurisdictional claims in published maps and institutional affiliations. 